\title{
Propagation of Sedum spectabile Boreau in Leaf Culture in Vitro
}

\author{
Cuiqin YANG ${ }^{1,2,3}$, Yaoguo $\mathrm{QIN}^{4}$, Xin SUN ${ }^{2}$, Shu YUAN ${ }^{1}$, Honghui LIN ${ }^{1}$ \\ ${ }^{1}$ Sichuan University, Key Laboratory of Bio-resources and Eco-environment (Ministry of Education), State Key Laboratory of \\ Hydraulics and Mountain River Engineering, College of Life Science, Chengdu 610065, P. R. China; honghuilin@hotmail.com \\ ${ }^{2}$ Sichuan Agricultural University, College of Agronomy, Chengdu 611130, P. R. China \\ ${ }^{3}$ Chinese Academy of Sciences, Chengdu Institute of Biology, Chengdu 610041, P. R. China \\ ${ }^{4}$ Sichuan Agricultural University, College of Horticulture, Yaian 625014, P. R. China
}

\begin{abstract}
An efficient protocol was established for Sedum spectabile Boreau propagation. Various leaf parts were used as explants to regenerate plantlets, the stem segments of which were cultured for shoot proliferation and plantlet multiplication. The results showed that the leaf base was the optimal explant, as compared to both the middle and the top of leaves, for shoot formation. The highest shoot induction of $88.9 \%$ was observed on MS medium supplemented with $0.6 \mathrm{mg} / \mathrm{l} \mathrm{TDZ}$ and $0.1 \mathrm{mg} / \mathrm{l} \mathrm{NAA}$. Hyperhydric leaves obtained in primary culture developed first into abnormal somatic embryos 10 days after subculture, and then into hyperhydric plantlets after an additional 10 days. The hyperhydric plantlets reversed to normal plantlets when plant growth regulators were removed from culture medium. Further, stem segments from reversed plantlets were used for shoot regeneration and root induction. Optimal shoot regeneration was obtained in MS medium containing $0.6 \mathrm{mg} / 1 \mathrm{TDZ}$ with $0.1 \mathrm{mg} / \mathrm{l} \mathrm{NAA}$. Root induction and root mean number were all higher on auxin-free medium than on medium containing auxins.
\end{abstract}

Keywords: hyperhydricity, leaf, reversion, tissue culture

\section{Introduction}

Sedum spectabile Boreau belongs to the Crassulaceae family and is widely distributed throughout the warm and temperate zones. It is an herbaceous perennial plant and has strong tolerance to drought (Rabas and Martin, 2003), low temperatures (Iles et al., 1993; Iles and Agnew, 1995), and shade (Jiang et al., 2007), all characteristics of wide adaptability and easy manageability. Cultivars of Sedum spectabile Boreau have showy white, pink, or red flowers, highlighting it as a fairly ornamental plant. It has also been reported to remedy polluted soil by $\mathrm{Hg}$ or Co (Wang et al., 2008).

Sedum spectabile Boreau is often propagated by either cutting or dividing its roots. These conventional methods, however, are slow and require a large number of parent propagules. It is thus important to study Sedum spectabile Boreau propagation to ultimately apply it to various uses, such as garden sets and medicinal cultivation. The in vitro culture system stands as a candidate for overcoming any prior deficiencies. Researchers have investigated in vitro cultures of Sedum spectabile Boreau using stem segments with terminal buds (Ren and Dong, 2006; Xing et al., 2010), intact leaves (Zhang and Cheng, 2007), and petals (Wojciechowicz, 2009) as explants. No further reports on morphogenesis and somatic embryo induction of leaf parts have been reported. In the study, different leaf parts were used as explants to investigate the morphogen- esis process. Hyperhydric plantlets were found to reverse to normal, and the stems of these reversed plantlets were used to regenerate shoots and roots for propagation. The effects of varying concentrations of plant growth regulators (PGRs) on the differentiation of leaves, hyperhydric shoots, and stem segments were analyzed to ultimately establish an efficient protocol for the propagation of Sedum spectabile Boreau.

\section{Materials and methods}

\section{Plant materials}

Leaves of Sedum spectabile Boreau cultivar 'Pink' were used in this study. Leaves were first washed in running tap water for 30 minutes, sterilized by $70 \%$ ethanol for 10 seconds followed by $0.1 \%$ mercuric chloride for 8 minutes, and finally washed five times in sterilized distilled water. Leaves were cut into three parts: leaf top, leaf middle, and leaf base (Fig. $1 \mathrm{~A}, \mathrm{~B}$ ), and cultured on primary culture media.

\section{Primary culture}

Treated leaves were inoculated on Murashige and Skoog (1962) (MS) medium supplemented with different concentrations of benzyladenine (BA; $0.5,1.0,2.0 \mathrm{mg} / \mathrm{l}$ ) or Thidiazuron (TDZ; $0.2,0.4,0.6 \mathrm{mg} / \mathrm{l}$ ) with $0.1 \mathrm{mg} / \mathrm{l}$ a-Naphthylacetic acid (NAA). MS medium without plant growth regulators (PGRs) was used as a control. 
108

Subculture-induction of hyperhydric leaves and reversion of hyperhydric plantlets

Hyperhydric leaves obtained from primary culture were inoculated on MS medium supplemented with 1.0 $\mathrm{mg} / \mathrm{l} \mathrm{BA}$ or $0.4 \mathrm{mg} / \mathrm{l} \mathrm{TDZ}$ with $0.1 \mathrm{mg} / \mathrm{l} \mathrm{NAA}$, and the effects of PGRs on their morphogenesis was discerned. MS medium without PGRs was used as a control.

Hyperhydric plantlets induced from hyperhydric leaves were cultured on PGR-free MS medium and MS medium containing $0.4 \mathrm{mg} / \mathrm{l} \mathrm{TDZ}$ and $0.1 \mathrm{mg} / \mathrm{l} \mathrm{NAA}$ to investigate factors affecting reversion.

Shoot development and root induction of stem segments from recovered plantlets

Stems of recovered plantlets were cut into $2-3 \mathrm{~cm} \mathrm{seg-}$ ments with three nodes and inoculated on MS medium supplemented with different concentrations of TDZ (0.2, $0.4,0.6 \mathrm{mg} / \mathrm{l}$ ) with $0.1 \mathrm{mg} / \mathrm{l} \mathrm{NAA}$ to regenerate shoots. The same stem segments were cultured on MS medium supplemented with NAA $(0.1,0.5,2.5 \mathrm{mg} / \mathrm{l})$ or indolebutyric acid (IBA; $0.1,0.5,2.5 \mathrm{mg} / \mathrm{l}$ ) to induce roots. MS medium without PGRs was used as a control.

\section{Acclimatization}

The rooted plantlets were potted in a mixture of humus and perlite $(2: 1, \mathrm{v}: \mathrm{v})$ and placed in a greenhouse exposed to a natural light/dark circle of sunlight at $24 \pm 2^{\circ} \mathrm{C}$ in $60 \%$ relative humidity.

\section{Culture condition}

The above culture media contained $30.0 \mathrm{~g} / \mathrm{l}$ sugar, 6.0 $\mathrm{g} / \mathrm{l}$ agar, and was adjusted to $\mathrm{pH} 5.8$ before autoclaving at a pressure of $105 \mathrm{kPa}$ for 20 minutes at $121^{\circ} \mathrm{C}$. All cultures were incubated under a $16 \mathrm{~h}$ photoperiod at $40 \mu \mathrm{mol} \mathrm{m}^{-2}$ $s^{-1}$ at $23 \pm 2^{\circ} \mathrm{C}$ in $70-80 \%$ relative humidity.

\section{Statistical analysis}

Each treatment consisted of 42 inoculated explants and was performed in triplicate when determining hyperhydric plantlet reversion. Five replicates were used per treatment with the 15 explants in the other experiments. All data was recorded after 4 weeks of culture and was analyzed for variance. Additionally, treatment means were compared using Duncan's multiple range test (Duncan, 1995) at 5\% significance.

\section{Results and discussion}

The morphogenesis of leaves in the primary culture

All leaves expanded a week after inoculation. Three types of organogenesis after swollenness were observed, Type I extended at twice to three times over original volume and showed hyperhydricity (Fig. 1 CI). Moreover, abnormal somatic embryo regenerated from these leaves and developed into hyperhydric plantlets (Fig. 1 E, F, G). Comparatively, type II samples were less swollen and normal shoots were initiated from the cut surface of the lower side of these leaves (Fig. 1 CII, D). Although type III sam-

Tab. 1. Leaf Morphogenesis 4 weeks after inoculation

\begin{tabular}{|c|c|c|c|c|c|}
\hline Explant type & $\begin{array}{c}\text { BA concentration } \\
(\mathrm{mg} / \mathrm{l})\end{array}$ & $\begin{array}{c}\text { TDZ concentration } \\
(\mathrm{mg} / \mathrm{l})\end{array}$ & $\begin{array}{c}\text { Embryo induction rate } \\
(\%)\end{array}$ & $\begin{array}{c}\text { Shoot induction rate } \\
(\%)\end{array}$ & $\begin{array}{c}\text { Mean shoot } \\
\text { number }\end{array}$ \\
\hline \multirow{7}{*}{ Leaf top } & 0 & 0 & $0 \mathrm{f}$ & $0 \mathrm{j}$ & $0 \mathrm{~g}$ \\
\hline & 0.5 & 0 & $0 \mathrm{f}$ & $0 \mathrm{j}$ & $0 \mathrm{~g}$ \\
\hline & 1.0 & 0 & $0 \mathrm{f}$ & $0 \mathrm{j}$ & $0 \mathrm{~g}$ \\
\hline & 2.0 & 0 & $14.3 \mathrm{~b}$ & $14.3 \mathrm{~h}$ & $0.1 \mathrm{f}$ \\
\hline & 0 & 0.2 & $0 \mathrm{f}$ & $33.3 \mathrm{e}$ & $0.7 \mathrm{c}$ \\
\hline & 0 & 0.4 & $0 \mathrm{f}$ & $50.0 \mathrm{c}$ & $0.3 \mathrm{e}$ \\
\hline & 0 & 0.6 & $8.3 \mathrm{e}$ & $25.0 \mathrm{f}$ & $0.6 \mathrm{~cd}$ \\
\hline \multirow{7}{*}{ Leaf middle } & 0 & 0 & $0 \mathrm{f}$ & $0 \mathrm{j}$ & $0 \mathrm{~g}$ \\
\hline & 0.5 & 0 & $11.1 \mathrm{~d}$ & $0 \mathrm{j}$ & $0 \mathrm{~g}$ \\
\hline & 1.0 & 0 & $50.0 \mathrm{a}$ & $0 \mathrm{j}$ & $0 \mathrm{~g}$ \\
\hline & 2.0 & 0 & $12.5 \mathrm{c}$ & $0 \mathrm{j}$ & $0 \mathrm{~g}$ \\
\hline & 0 & 0.2 & $0 \mathrm{f}$ & $60.0 \mathrm{~b}$ & $2.4 \mathrm{a}$ \\
\hline & 0 & 0.4 & $8.3 \mathrm{e}$ & $25.0 \mathrm{f}$ & $0.4 \mathrm{de}$ \\
\hline & 0 & 0.6 & $0 \mathrm{f}$ & $50.0 \mathrm{c}$ & $0.5 \mathrm{cde}$ \\
\hline \multirow{7}{*}{ Leaf base } & 0 & 0 & $0 \mathrm{f}$ & $0 j$ & $0 \mathrm{~g}$ \\
\hline & 0.5 & 0 & $0 \mathrm{f}$ & $0 \mathrm{j}$ & $0 \mathrm{~g}$ \\
\hline & 1.0 & 0 & $11.1 \mathrm{~d}$ & $11.1 \mathrm{i}$ & $0.1 \mathrm{f}$ \\
\hline & 2.0 & 0 & $0 \mathrm{f}$ & $0 \mathrm{j}$ & $0 \mathrm{~g}$ \\
\hline & 0 & 0.2 & $0 \mathrm{f}$ & $44.4 d$ & $0.6 \mathrm{~cd}$ \\
\hline & 0 & 0.4 & $11.1 \mathrm{~d}$ & $22.2 \mathrm{~g}$ & $0.7 \mathrm{c}$ \\
\hline & 0 & 0.6 & $11.1 \mathrm{~d}$ & $88.9 \mathrm{a}$ & $1.7 \mathrm{~b}$ \\
\hline
\end{tabular}

Note: Different letters in the same line denote significant differences (Duncan's test, $p<0.05$ ) 
ples were also less swollen, there existed no visible changes after a month (Fig. 1 CIII).

Small structures emerged from the edges of hyperhydric leaves (Type I) 3 weeks after inoculation. These structures became scattered and independent after 4 weeks and finally developed into abnormal, hyperhydric somatic embryos (Fig. $1 \mathrm{E}$ ). Embryo induction of the leaf middle reached the highest rate of $50.0 \%$ on medium containing $1.0 \mathrm{mg} / \mathrm{l}$ BA. The highest embryo induction rates of leaf top and leaf base were $14.3 \%$ and $11.1 \%$, respectively (Tab. 1). Enlarged leaves and induced somatic embryos, however, were all hyperhydric (Fig. 1 E, F). Hyperhydricity is also known as 'vitrification' in fact, Franck et al. (2004) characterized hyperhydric materials by their translucent aspect from chlorophyll deficiency, undeveloped cell wall, and high water content. Moreover, Rojas-Martínez et al. (2010) defined the hyperhydricity phenomenon as a physiological disorder in tissue-cultured plant material, resulting from waterlogging and apoplast stresses. A reason for hyperhydricity may be due to the different physiological explant statuses. The physiological states of leaves were different at various attachment regions on the same plantlet. Leaves from differing nodes showed varied morphology in identical medium, with only some being hyperhydric. Another potential reason is a high PGR concentration. Kadota and Niimi (2003) reported that TDZ and CPPU caused greater hyperhydricity than $\mathrm{BA}$ when culturing pear cultivar in vitro, but BA caused higher leaf hyperhydricity than TDZ in the present study.

Shoots were induced on type II leaves. Medium containing $0.2-0.6 \mathrm{mg} / \mathrm{l} \mathrm{TDZ}$ and $0.1 \mathrm{mg} / \mathrm{l} \mathrm{NAA}$ was more effective in multiple shoot inductions than that containing $0.5-2 \mathrm{mg} / \mathrm{l} \mathrm{BA}$ and $0.1 \mathrm{mg} / \mathrm{l} \mathrm{NAA}$. The highest rates of shoot induction from leaf top, leaf middle, and leaf base
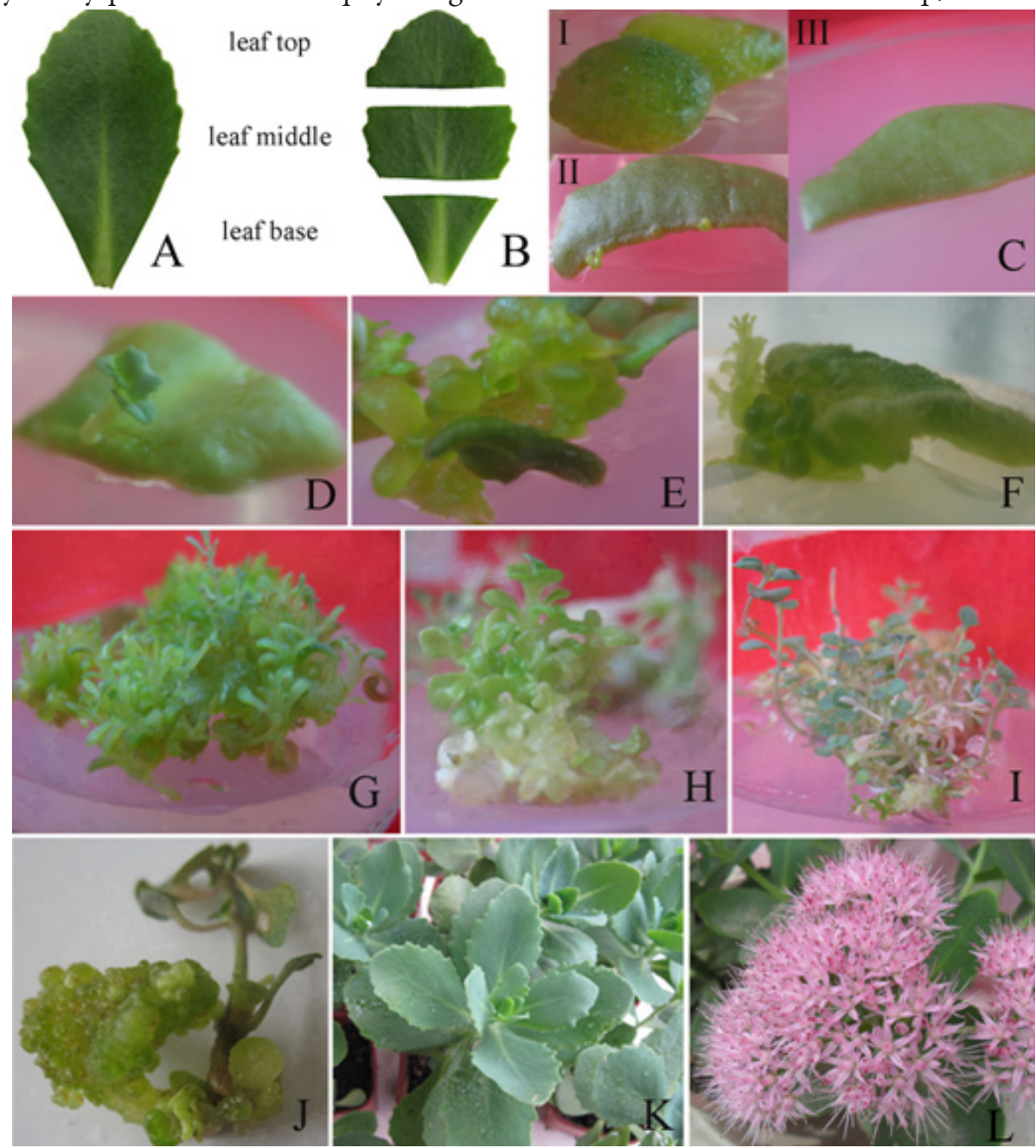

Fig. 1. Leaf explant preparation, regeneration, and micropropagation of Sedum spectabile Boreau. (A) and (B) Leaf explants preparation; (C) I, II, III. Three types of organogenesis of one leaf: type I (leaf base), type II (leaf top) and type III (leaf top), respectively; (D) Shoot regeneration of leaf base explants in culture after 3 weeks; (E) Abnormal somatic embryos from leaf explants after 4 weeks in culture; (F) Organogenesis of hyperhydric leaves after 2 weeks of subculture; (G) Hyperhydric plantlets from hyperhydric somatic embryos; (H) Intermediate type of hyperhydric and normal plantlets; (I) Normal plantlets from hyperhydric plantlets after 4 weeks of culture on PGR-free MS medium; (J) Organogenesis of stem segments from reversed plantlets on MS medium supplemented with $0.6 \mathrm{mg} / \mathrm{l} \mathrm{TDZ}$ and $0.1 \mathrm{mg} / \mathrm{l} \mathrm{NAA}$; (K) Acclimatization of leaf-derived plantlets; (L) Flowering of leaf-derived plantlets 
110

were detected on medium containing $0.4 \mathrm{mg} / \mathrm{l}, 0.2 \mathrm{mg} / \mathrm{l}$, and $0.6 \mathrm{mg} / \mathrm{l} \mathrm{TDZ}$, respectively. Leaf base had the highest induction rate of $88.9 \%$ compared to the other leaf parts. Additionally, it was observed that all shoots grew from the morphologic leaf bottoms (Fig. 1 CII, D), indicating the existence of leaf polarity under certain induction conditions.

\section{Effects of PGRs on the morphogenesis of hyperhydric leaves and plantlets}

Since the embryo induction rate of leaf middle and leaf base on media containing $1.0 \mathrm{mg} / \mathrm{l} \mathrm{BA}$ or $0.4 \mathrm{mg} / \mathrm{l} \mathrm{TDZ}$ with $0.1 \mathrm{mg} / \mathrm{l} \mathrm{NAA}$ was high in primary culture, this culture medium was selected to subculture hyperhydric leaves. The first abnormal somatic embryogenesis was observed 10 days after subculture in medium containing 1.0 $\mathrm{mg} / \mathrm{l} \mathrm{BA}$, which then began to differentiate after 20 days. No significant difference between embryo induction and differentiation rate was observed in medium containing $0.4 \mathrm{mg} / \mathrm{l} \mathrm{TDZ}$ and $1.0 \mathrm{mg} / \mathrm{l} \mathrm{BA}$, whereas significant difference was observed when this was compared to the control for induction (Tab. 2). Although abnormal somatic embryos developed into plantlets after 20 days of subculture, plantlets showed a lower differentiation level without roots and were hyperhydric (Fig. $1 \mathrm{G}$ ). These monstrous plantlets should be reversed into normal plantlets before being transplanted for garden sets.

After inoculation on culture medium with PGRs for 4 weeks, plantlets still remained in a state of hyperhydricity, not producing roots. Hyperhydric plantlets, however, began to reverse, and slender leaves turned normal and obvated, and started to root on PGR-free medium after 3 weeks (Fig. $1 \mathrm{H}, \mathrm{I}$ ). The reversion rate of hyperhydricity was $89.2 \%$, and rooting rate achieved was $82.3 \%$. PGRs were the main factors affecting hyperhydricity of Sedum spectabile Boreau, possibly through the concentration of cytokinins. Kevers et al. (1984) reported that excess of either cytokinins or $\mathrm{NH}_{4}^{+}$ions indirectly led to cellulose and lignin deficiencies, allowing increased water uptake from reduced wall pressure, bringing about hyperhydric malformations. Recently, Yu et al. (2011) argued that zeatin was the most important factor for hyperhydricity, followed by sucrose concentration, $\mathrm{AgNO}_{3}$, and indoleacetic acid. Additionally, other studies also showed that cytokinins caused hyperhydricity in vitro (Debergh $e t$ al., 1981; Debergh and Maene 1984; Pagues et al., 1987). In the pre study, the hyperhydric phenomenon occurred in almost all culture media containing high concentrations of cytokinins.

In addition to PGRs, agar concentration $(6,7$ and 8 $\mathrm{g} / \mathrm{l})$ and $\mathrm{pH}$ value $(5.8,6.4$ and 7.0$)$ were investigated for hyperhydric plantlet reversion (data not shown). These two factors affected water content, chlorophyll, and anthocyanin synthesis, and ultimately, could not induce normal plantlets from hyperhydric ones. Previous studies indicated that increased agarose concentration could reduce hyperhydricity rate (Borman and Vogelmann, 1984; Debergh, 1983), yet this result could not be repeated in the present study, most likely due to differences in plant materials.

Humidity (Curtis and Shetty, 1996), subculture times (Tsay, 1998), and soft culture media all (Kevers et al., 2004) could influence hyperhydricity. Saher et al. (2005a, 2005b) studied a mechanism of hyperhydricity, discovering that different pectin methyl esterase (PME) activities influence structural changes related to hyperhydricity in micropropagated carnation plants. Hyperhydric leaves of carnations adapted to hypoxia stress conditions through both oxidative pentose phosphate and fermentative pathway induction. It remains difficult to clarify physiological causes of hyperhydricity, mainly due to the multiplicity of factors involved in this process.

\section{Regeneration of stem segments from plantlets}

Shoot regeneration rate on culture media with PGRs was higher than on media without PGRs (Tab. 3). Moreover, the average number of shoots increased with higher TDZ concentration. The optimal effect of shoot induc-

Tab. 2. Subculture induction of hyperhydric leaves

\begin{tabular}{|c|c|c|c|}
\hline $\begin{array}{l}\text { Concentration combination } \\
\text { of cytokinin and auxin } \\
(\mathrm{mg} / \mathrm{l})\end{array}$ & $\begin{array}{l}\text { Embryo induction rate } \\
(\%)\end{array}$ & $\begin{array}{c}\text { Mean differentiation rate } \\
(\%)\end{array}$ & Growth state \\
\hline 0 & $0 \mathrm{~b}$ & $0 \mathrm{~b}$ & $\begin{array}{l}\text { Hyperhydric leaves began to lose green, and } \\
\text { showed yellow, brown; died after inoculation. }\end{array}$ \\
\hline BA $1.0+$ NAA 0.1 & $70.0 \mathrm{a}$ & $66.7 \mathrm{a}$ & $\begin{array}{l}\text { Some remained green and exhibited no change; } \\
\text { others produced abnormal somatic embryos } \\
\text { that soon differentiated into hyperhydric } \\
\text { plantlets with slender and fleshy leaves, } \\
\text { thick and fleshy stems, and no roots. }\end{array}$ \\
\hline TDZ 0.4 + NAA 0.1 & $69.2 \mathrm{a}$ & $65.5 \mathrm{a}$ & $\begin{array}{l}\text { Some remained green and exhibited no change; } \\
\text { others produced abnormal somatic embryos } \\
\text { that soon differentiated into hyperhydric } \\
\text { plantlets with slender and fleshy leaves, } \\
\text { thick and fleshy stems, and no roots. }\end{array}$ \\
\hline
\end{tabular}

Note: Different letters in the same line denote significant differences (Duncan's test, $p<0.05$ ) 
Tab. 3. Effects of different PGRs on induction of shoots

\begin{tabular}{ccccc}
\hline $\begin{array}{c}\text { TDZ concentrations } \\
(\mathrm{mg} / \mathrm{l})\end{array}$ & $\begin{array}{c}\text { NAA concentrations } \\
(\mathrm{mg} / \mathrm{l})\end{array}$ & $\begin{array}{c}\text { Shoot regeneration rate } \\
(\%)\end{array}$ & Mean shoot number & $\begin{array}{c}\text { Callus induction rate } \\
(\%)\end{array}$ \\
\hline 0 & 0 & $61.1 \mathrm{c}$ & $1.9 \mathrm{~d}$ & $0 \mathrm{~d}$ \\
0.2 & 0.1 & $100.0 \mathrm{a}$ & $2.5 \mathrm{c}$ & $27.8 \mathrm{~b}$ \\
0.4 & 0.1 & $91.7 \mathrm{~b}$ & $3.3 \mathrm{~b}$ & $58.3 \mathrm{a}$ \\
0.6 & 0.1 & $100.0 \mathrm{a}$ & $3.8 \mathrm{a}$ & $22.2 \mathrm{c}$ \\
\hline
\end{tabular}

Note: Different letters in the same line denote significant differences (Duncan's test, $p<0.05$ )

tion was obtained on culture medium containing $0.6 \mathrm{mg} / \mathrm{l}$ TDZ with $0.1 \mathrm{mg} / \mathrm{l}$ NAA. Most induced shoots were axillary (Fig. $1 \mathrm{~J}$ ). Embryonic callus was induced 3 weeks after inoculation from the base of stem segments on culture media containing PGRs (Fig. $1 \mathrm{~J}$ ). The highest callus induction rate was detected on culture medium containing $0.4 \mathrm{mg} / \mathrm{l} \mathrm{TDZ}$ with $0.1 \mathrm{mg} / \mathrm{l} \mathrm{NAA}$. The obtained callus had strong regeneration ability (data not shown) and is a valid propagation material. Ren and Dong (2006) reported that a single bud developed into axillary buds on MS medium with $0.1 \mathrm{mg} / \mathrm{l} \mathrm{BA}$ and $0.1 \mathrm{mg} / \mathrm{l} \mathrm{NAA}$, and finally into plexus buds. The callus was first shaped from the stem base, and then differentiated into shoots, similar to the present results.

The rooting results show that root induction rate and mean number were higher on auxin-free medium than on medium containing auxins. IBA was superior to NAA for rooting among treatments supplemented with auxins ( Tab. 4). Rooted plantlets hardened after 4 weeks with a $100 \%$ survival rate. Healthy plants were obtained with normal flowers into the next year (Fig. $1 \mathrm{~K}, \mathrm{~L}$ ).

Tab. 4. Effects of different PGRs on root induction

\begin{tabular}{cccc}
\hline $\begin{array}{c}\text { NAA } \\
\begin{array}{c}\text { concentrations } \\
(\mathrm{mg} / \mathrm{l})\end{array}\end{array}$ & $\begin{array}{c}\text { IBA } \\
\text { concentrations } \\
\mathrm{mg} / \mathrm{l})\end{array}$ & $\begin{array}{c}\text { Root } \\
\text { induction rate } \\
\%)\end{array}$ & $\begin{array}{c}\text { Mean root } \\
\text { number }\end{array}$ \\
\hline 0 & 0 & $100.0 \mathrm{a}$ & $18.5 \mathrm{a}$ \\
0.1 & 0 & $55.6 \mathrm{c}$ & $9.3 \mathrm{c}$ \\
0.5 & 0 & $94.4 \mathrm{~b}$ & $9.0 \mathrm{c}$ \\
2.5 & 0 & $94.4 \mathrm{~b}$ & $13.5 \mathrm{c}$ \\
0 & 0.1 & $100.0 \mathrm{a}$ & $17.0 \mathrm{a}$ \\
\hline 0 & 0.5 & $100.0 \mathrm{a}$ & $13.3 \mathrm{~b}$ \\
0 & 2.5 & $100.0 \mathrm{a}$ & $11.9 \mathrm{~b}$ \\
\hline
\end{tabular}

Note: Different letters in the same line denote significant differences (Duncan's test, $p<0.05$ )

\section{Conclusions}

Hyperhydric leaves obtained in primary culture developed into somatic embryos, and then formed hyperhydric plantlets after subculture. Hyperhydric plantlets reversed and turned to normal plantlets by removing PGRs from culture media. The study showed that plant growth regulators potently affected hyperhydricity of Sedum spectabile Boreau. Additionally, the number of normal plantlets obtained from hyperhydric leaves was much more than the amount of shoots induced directly from normal leaves.
Recovered plantlets flowered normally. With these results, a successful and effective pathway for Sedum spectabile Boreau propogation was concluded.

\section{Acknowledgements}

This work was supported by the National Nature Science Foundation of China (91017004, 31070210, 31000682 , and 30970214) and the Sichuan Nature Science Foundation (2010JQ0080).

\section{References}

Borman CH, Vogelmann TC (1984). Effect of rigidity of gel medium on benzyladenine-induced adventitious bud formation and vitrification in vitro in Picea abies. Physiol Plantarum 61:505-512.

Curtis OF, Shetty K (1996). Growth medium effects of vitrification, total phenolics, chlorophyll, and water content of in vitro propagated oregano clones. Acta Hortic 426:489497.

Debergh PC (1983). Effects of agar brand and concentration on the tissue culture medium. Physiol Plantarum 59:270-276.

Debergh P, Harbaoui Y, Lemeur R (1981). Mass propagation of globe artichoke (Cynara scolymus): evaluation of different hypotheses to overcome vitrification with special reference to water potential. Physiol Plantarum 53:181-187.

Debergh PC, Maene LJ (1984). Pathological and physiological problems related to the in vitro culture of plants. Parasitia 40:69-75.

Duncan DB (1995). Multiple range and multiple F test. Biometrics 11:1-42.

Franck T, Kevers C, Gaspar T, Dommes J, Deby C, Greimers R, Serteyn D, Deby-Dupont G (2004). Hyperhydricity of Prunus avium shoots cultured on gelrite: a controlled stress response. Plant Physiol Bioch 42:519-527.

IlesJK, Agnew NH, Taber HG, Christians NE (1993). Evaluation of structureless overwintering systems for container-grown herbaceous perennials. J Environ Horti 11(2):48-55.

Iles JK, Agnew NH (1995). Seasonal cold-acclimation patterns of Sedum spectabile x telephium L. 'Autumn Joy' and Sedum spectabile. 'Brilliant'. Hort Sci 30:1221-1224.

Jiang D, Xiao W, Ding P, Wu YH, Yang YH, Sun XG (2007). A Study on the adaptability of fourteen types of shadetolerance plants in the special space in Lanzhou city. J Northwest For Univ 22(2):28-32 (in Chinese). 
112

Kadota M, Niimi Y (2003). Effects of cytokinin types and their concentrations on shoot proliferation and hyperhydricity in in vitro pear cultivar shoots. Plant Cell Tiss Org 72:261265.

Kevers C, Coumans M, Coumans-Gillès MF, Caspar T (1984). Physiological and biochemical events leading to vitrification of plants cultured in vitro. Physiol Plantarum 61:69-74.

Kevers C, Franck T, Strasser RJ, Dommes J, Gaspar T (2004). Hyperhydricity of micropropagated shoots: a typically stress-induced change of physiological state. Plant Cell Tiss Org 77:181-191.

Murashige T, Skoog F (1962). A revised medium for rapid growth and bioassays with tabocco tissue cultures. Physiol Plantarum 15:473-479.

Paques M, Boxus P (1987). "Vitrification": review of literature. Acta Hortic 212:156-166.

Rabas AR, Martin CE (2003). Movement of water from old to young leaves in three species of succulents. Ann Bot 92:529536.

Ren SY, Dong L (2006). Tissue culture and rapid propagation of Sedum spectabile 'Star Dust'. Plant Physiol Comm 42:246 (in Chinese).

Rojas-Martinez L, Visser RGF, de Klerk GJ (2010). The hyperhydricity syndrome: waterlogging of plant tissues as a major cause. Propag Ornam Plants 10:69-175.

Saher S, Fernández-García N, Piqueras A (2005a). Reducing properties, energy efficiency and carbohydrate metabolism in hyperhydric and normal carnation shoots cultured in vitro: a hypoxia stress? Plant Physiol Bioch 43:573-582.
Saher S, Piqueras A, Hellin E, Olmos E (2005b). Pectin methyl esterases and pectins in normal and hyperhydric shoots of carnation cultured in vitro. Plant Physiol Bioch 43:155159.

Tsay HS (1998). Effects of medium compositions at different recultures on vitrification of carnation (Dianthus caryophyllus) in vitro shoot proliferation. Acta Hortic 461:243-249.

Xing MM, Shen M, Gao XH, Wang ZZ, Leng PS (2010). Tissue culture and rapid propagation of two sedum cultivars. J Beijing Univ Agric 25:65-68 (in Chinese).

Wang Y, Dai BQ, Xin SG, Kang YH, Li N (2008). Physiological responses and absorption of heavy metals by Sedum spectabile under the stress of combined heavy metal pollution. J AgroEnviron Sci 27:1051-1056 (in Chinese).

Wojciechowicz MK (2009). Organogenesis and somatic embryogenesis induced in petal cultures of Sedum species. Acta Biol Cracov Bot 51:83-90.

Yu U, Zhao YQ, Zhao B, Ren S, Guo YD (2011). Influencing factors and structural characterization of hyperhydricity of in vitro regeneration in Brassica oleracea var. italica. Can J Plant Sci 91:59-165.

Zhang XY, Cheng YQ (2007). Tissue culture and rapid propagation of Sedum spectabile Boreau. J Jilin Normal Univ (Natural Science Edition) 2:60-62 (in Chinese). 